\title{
PEMBERDAYAAN PERPUSTAKAAN SEBAGAI SARANA DAKWAH
}

\section{Kobana Salam}

\author{
Pustakawan pada Universitas Tadulako Palu
}

Nurdin Nurdin

email: nnurdin@iainpalu.ac.id

Dosen Tetap Pada Jurusan Komunikasi dan Penyiaran Islam IAIN Palu

\section{Abstract:}

Librrary is a important source of information for community. A number of research has been carried out to understand how libraries are utilized in supporting community and educational institutions need of information. Instaed dakwah is understood as an activity which heavily dealing with information, little is studies has been carried out to understand how a library can be used to support dakwah activities. This paper shed light how libraries can also be used for dakwah purposes. Through extensive literature review, we found that libraries can also be utilized as instrument to support dakwah activities. A library can provide rich information for every Muslim and Dai in dakwah activities. A lbrary can also be used for self-learning activities relating to islamic teaching, and a library can preserve Islamic valuable historical document and artefact for new Muslim generation. Finally, Muslim can use library as a place to obtain inspiration and ideas through self-study and research. The limitation of this paper is that the data merely relied on litarature review and future research need to be carried out to obtain empirical data.

$$
\begin{aligned}
& \text { ومن المعلوم أن المكتبة هي مصدر المعلومات المهم بالنسبة للمجتمع. و قد أجري عدد من البحوث المباث }
\end{aligned}
$$

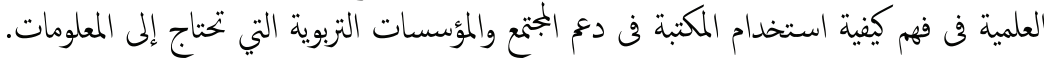

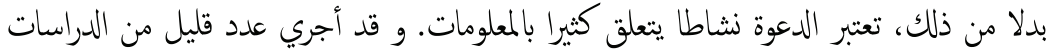

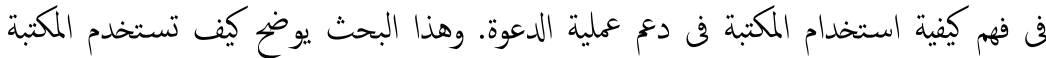

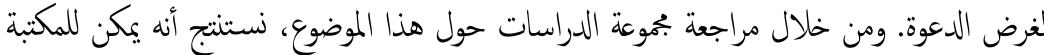

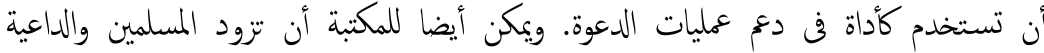

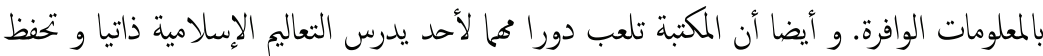

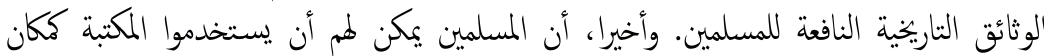


Kobana Salam, Nurdin Nurdin, Pemberdayaan Perpustakaan.....

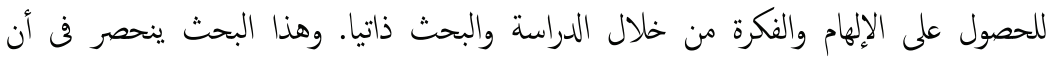

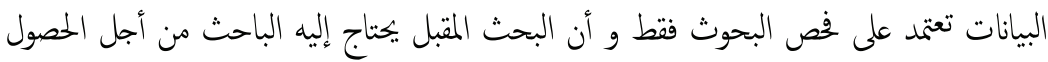

$$
\begin{aligned}
& \text { على البيانات التجريبية. }
\end{aligned}
$$

Kata Kunci: perpustakaan, pemberdayaan, dakwah, Islam

\section{Latarbelakang}

Perpustakaan merupakan sarana vital dalam kehidupan masyarakat yang moderen dan terpelajar. Freeman dengan tegas mengatakan bahwa perpustakaan sebagai jantungnya sebuah lembaga baik secara simbolis maupun secara fisik ${ }^{1}$. Dalam kontek perguruan tinggi, maka perustakaan bisa dimaknai sebagai jantungnya perguruan tinggi. Jika kita menganggap perpustakaan seperti jantung pada tubuh manusia, maka kita sudah memahami bahwa fungsi dari jantung tersebut adalah memompa darah keseluruh tubuh untuk menopang kehidupan seluruh komponen dalam tubuh manusia. Informasi yang ada di perpustakaan adalah bagai darah yang ada dalam tubuh manusia dimana informasi tersebut menopang kehidupan seluruh komponen civitas akademik yang ada dalam kampus. Tanpa informasi maka mustahil kegiatan akademik dapat berlangsung.

Perpustakaan sebagai pusat informasi maka memegang peranan penting dalam perannya sebagai information disseminator. Bahkan Irsan mengatakan perpustakaan merupakan tempat para "pendakwah" yang dapat menyampaikan ceramah agamanya melalui berbagai informasi yang ada didalamnya terutama koleksi cetak melalui membuka halamannya ${ }^{2}$. Pendakwah yang sering disebut dengan da'i merupakan

${ }^{1}$ Freeman, G. T. The Library as Place: Changes in Learning Patterns, Collections, Technology, and Use. In K. Smith (Ed.), Library as Place: Rethinking Roles, Rethinking Space. (Washington DC: Council on Library and Information Resources, 2005), h. 1

${ }^{2}$ Irsan. (Ziarah Perpustakaan Di Makassar). 2014. Retrieved 25 Oktober 2015, from Wordpress https://airsunblog.wordpress.com/2014/09/26/ziarah-perpustakaan-dimakassar/ 


\section{$\Delta L-$-nish $3 \bar{\Delta} /$ H, Vol. 11 No. 1, Januari-Juni 2015: 47-64}

orang yang menyampaikan ajaran Islam kepada masyarakat penerima dakwah $^{3}$. Penyampaian ajaran ini tentu melalui pengkajian berbagai sumber informasi yang dipelajari oleh para da'i tersebut misalnya alquran, kumpulan hadis, buku-buku, dan lain-lain.

Elemen-elemen perpustakaan yang dapat berperan penting sebagai pendakwah tidak hanya koleksi tapi juga para pustakawan. Pustakawan dapat bertanggung jawab mempersiapkan berbagai informasi ke Islaman yang dapat disampaikan kepada pemustaka (umat Islam) ataupun dapat menyampaikan langsung melalui berbagai sarana penyebaran informasi. Dengan adanya peran pustakawan dalam menyiapkan berbagai informasi ke Islaman maka proses penyebaran ajaran-ajaran Islam akan lebih cepat sampai kepada umat.

Dengan demikian pemanfaatan perpustakaan dengan seluruh elemen yang ada didalamnya sebagai sarana dakwah perlu mendapat perhatian yang lebih baik dari berbagai kalangan, baik pemerintah, kampus, maupun tokoh-tokoh agama. Namun saat ini masih sangat minim informasi dan penelitian-penelitian tentang bagaimana sebaiknya membedayakan perpustakaan sebagai sarana penyampaian dakwah kepada umat Islam. Untuk itu, tulisan ini berusaha memberikan informasi tentang bagaimana memberdayakan pepustakaan bagi kepentingan dakwah melalui kajian berbagai literatur. Haparan penulis, tulisan ini bisa meanjadi batu loncatan terhadap lahirnya penelitian empiris kedepan terkait topik ini. Untuk itu penulis merumuskan pertanyaan tulisan ini sebagai berikut:

Bagaimana cara memberdayakan perpustakaan sebagai sarana dakwah agama Islam?

Tulisan ini ditulis dengan struktur sebagai berikut; setelah bagian latarbelakang akan dibahas pendekatan penulisan paper ini, kemudian dibagian ketiga akan dibahas pengetian perpustkaan dan dakwah,

${ }^{3}$ Suyuti, A. Amtsilatu Tasrifiyah. Yogyakarta: Mitra Pustaka, 1997), h. 11 
Kobana Salam, Nurdin Nurdin, Pemberdayaan Perpustakaan.....

dibagian ke empat akan dibahas beberapa fungsi perpustakaan dalam masyarakat, selanjutnya dibagian ke lima akan dibahas pemberdayaan perpustakaan sebagai sarana dakwah, kesimpulan dan saran akan dibahas dibagian akhir tulisan ini.

\section{Beberapa Definisi}

\section{a. Perpustakaan}

Kata perpustakaan diartikan sebagai "buku" yang dalam berbagai bahasa asing di istilahkan berbeda-beda. Dalam bahasa Arab, kata perpustakaan diasosiasikan dengan kata "al-maktabah" yang artinya buku, dalam bahasa Belanda di sebut dengan "Biliotheque" yang artinya juga buku. Jadi singkatnya kata perpustakaan itu pada mulanya dipahami sebagai tempat menyimpan buku dan koleksi cetak lainnya.

Pengertian perpustakaan yang paling sering dikutip oleh sejumlah penulis adalah definisi yang dikemukakan oleh Sulistiyo Basuki ${ }^{4}$ (1991, p. 3) sebagai berikut :

"perpustakaan adalah sebuah ruangan, bagian sebuah gedung, ataupun gedung itu sendiri yang digunakan untuk menyimpan buku dan terbitan lainnya yang biasanya disimpan menurut tata susunan tertentu untuk digunakan pembaca, bukan untuk dijual. Dalam pengertian buku dan terbitan lainnya termasuk didalamnya semua bahan cetak (buku, majalah, laporan, pamplet, prosiding, manuskrip (naskah), lembaran musik, berbagai karya media audio visual seperti film, slaid, kaset, piringan hitam, bentuk mikro seperti mikro film, mikrofis, dan mikro buram"5.

Sementara itu, Undang-Undang Perpustakaan Nomor 43 tahun 2007 mendefinisikan "Perpustakaan adalah institusi pengelola koleksi

${ }^{4}$ Basuki, S. Teknik dan Jasa Dokumentasi. Jakarta Gramedia Pustaka Utama, 1991), h. 3

${ }^{5}$ Ibid 


\section{$\Delta L-$-nish $3 \bar{\Delta} /$ H, Vol. 11 No. 1, Januari-Juni 2015: 47-64}

karya tulis, karya cetak, dan/atau karya rekam secara profesional dengan sistem yang baku guna memenuhi kebutuhan pendidikan, penelitian, pelestarian, informasi, dan rekreasi para pemustaka ${ }^{6}$ (Indonesia, 2007).

Selanjutnya Asosiasi Federasi Perpustakaan Internasional mendefinisikan perpustakaan sebagai " a means of access to information, ideas and works of imagination ${ }^{7}$. Dari ketiga definisi tersebut dapat kita rumuskan bahwa perpustakaan sebenarnya adalah sarana untuk memperoleh berbagai informasi baik yang tercetak maunpun dalam bentuk digital.

Perpustakaan itu memainkan peranan yang sangat penting dalam berbagai organisasi baik pemerintah maupun swasta karena menyediakan berbagai informasi sebagai sumber utama dalam pengambilan berbagai keputusan. Lembaga-lembaga akademis malah menganggap perpustakaan itu sebagai jantung mereka seperti yang disebutkan oleh Freeman yaitu " the academic library has always held a central position as the heart of an institution - both symbolically and in terms of its physical placement $^{8}$ (p.1). Ini berarti sebuah institusi hampir tidak mungkin dapat beroperasi tanpa perpustakaan.

Perpustakaan itu sendiri memiliki beberapa fungsi menurut Lasa HS, yang antara lain yaitu: sebagai sumber informasi, sebagai tempat studi/belajar, sebagai tempat menyimpan dokumentasi, sebagai tempat tumbuhnya ilham, inspirasi dan rekreasi, sebagai tempat pengumpul dan penyimpan terbitan tentang daerah/negaranya atau bidang ilmu tertentu,

'Indonesia. Undang-Undang Republik Indonesia Nomor 43 Tahun 2007 Tentang Perpustakaan, 2007), h 2

${ }^{7}$ IFLA. Information for All : The Key Role of Libraries in the Information Society (pp. 17). Geneva: INTERNATIONAL FEDERATION OF LIBRARY ASSOCIATIONS AND INSTITUTIONS (IFLA), 2003), h..2

${ }^{8}$ Freeman, G. T. The Library as Place: Changes in Learning Patterns, Collections, Technology, and Use. In K. Smith (Ed.), Library as Place: Rethinking Roles, Rethinking Space.( Washington DC: Council on Library and Information Resources, 2005), h. 35 
Kobana Salam, Nurdin Nurdin, Pemberdayaan Perpustakaan.....

dan sebagai pusat kegiatan peradaban manusia ${ }^{9}$. Dari definisi dan fungsi perpustakaan, dapat kita pahami bahwa perpustakaan dapat menjadi sarana yang potensial untuk dimanfaatakan untuk penyediaan dan penyampaian informasi terkait berbagai bidang ilmu termasuk Dakwah.

\section{Dakwah}

Da'wah didefinisikan sebagai usaha membujuk orang untuk melakukan hal-hal baik dan menjauhi segala larangan dengan berpegang teguh pada panduan yang benar ("inciting people to do good things and hold right guidance; to command the right thing and forbid the wrong one" $)^{10}$. Sementara itu dalam definisi lainnya, dakwah di pahami sebagai "suatu proses penyampaian pesan berkaitan dengan ajaran Islam dalam bentuk kasih sayang terhadap duniawi melalui pelbagai saluran media melalui metode seruan yang meyakinkan yang akan menghasilkan kesan tertentu ${ }^{11}$. Namun dakwah juga yang berarti mengajak, juga dapat dipahami dalam berbagai istilah lain seperti propaganda, penerangan, dan penyiaran ${ }^{12}$.

Dalam definisi tersebut terdapat dua hal penting yaitu membujuk (persuade) orang untuk melakukan hal yang baik dan media yang digunakan untuk menyampaikan bujukan tersebut. Dalam sejumlah literatur yang kita baca, media itu ada berbagai bentuknya mulai dari media cetak (seperti buku, mejalah, korang, buletin, dan lain-lain), media electronik (seperti televisi dan radio), media online (seperti internet), dan

${ }^{9}$ Lasa, H. Kamus Istilah Perpustakaan. (Yogyakarta Kanisius, 1993), h. 49

${ }^{10}$ Hamid, I. al-Da'wah Ila Allah bi al-Hikmah wa al-Maw'izah al-Hasanah. Mesir: al-Hay'ah al-Mis\}riyyah al-'Ammah, 1996), h.13

${ }^{11}$ Suhaimi, Dakwah and Communication Programmes in Tertiary Higher Education in Indonesia: A Brief Survey.( Islamiyyat, 34, 2012), 145-149.

${ }^{12}$ Natsir, M. Fiqhud Dakwah. (Jakarta: Dewan Dakwah Islamiah Indonesia, 1977), h. 31 


\section{$\Delta L-\cap i s h \exists \bar{d} h$, Vol. 11 No. 1, Januari-Juni 2015: 47-64}

bahkan media baru yang sangat terkenal saat ini yaitu media sosial (seperti Facebook, twitter, blog, Youtube, dll). Perpustakaan sebagai salah satu entitas penyedia informasi menyediakan semua media untuk mengakses informasi.

Dakwah sebagai usaha terwujudnya ajaran Islam pada semua segi kehidupan manusia, merupakan kewajiban bagi setiap muslim ${ }^{13}$. Penyampain pesan atau informasi tentang ajaran Islam dilakukan secara sadar dan terencana dengan menggunakan cara-cara tertentu untuk mempengaruhi orang lain agar dapat mengikuti atau berbuat seperti yang diinginkan oleh menjadi tujuan dakwah tersebut tanpa ada paksaan.

\section{Pendekatan tulisan ini}

Tulisan ini merupan hasil kajian pustaka yang dilakukan secara ektensive. Dalam hal ini kami para penulis semata-mata menggunakan data sekunder melalui kajian pustakan yang mendalam terhadap berbagai literature dalam bidang ilmu perpustakaan dan informasi, dan juga literature-literature yang terkait dengan dakwah dan komunikasi Islam. Metode kajian pustaka sudah lazim digunakan dalam melakukan suatu kajian ilmiah dalam menghasilkan sebuah ilmiah. Metode ini dilakukan dengan cara mengakaji berbagai literature terdahulu guna melahirkan ide-ide baru untuk dimanfaatkan dimasa mendatang ${ }^{14}$. Dalam melakukan analisis, penulis menggunakan pendekatan "thematic" atau "conceptual categories" dimana hasil kajian berbagai referensi di organisasikan menurut topik atau issue ${ }^{15}$ yang kami kaji. Dengan kata lain

${ }^{13}$ Mulyana, D. Nuansa-Nuansa Komunikasi Masyarakat Kontemporer (1 ed.). (Bandung: Remaja Rosdakarya, 1999), h. 54

${ }^{14}$ Webster, J., \& Watson, R. T. Analyzing the Past to Prepare for the Future: Writing a Literature Review, (MIS Quarterly, 26(2), 2002), h. 10.

${ }^{15}$ Labaree, R. Organizing Your Social Sciences Research Paper: The Literature Review (2013). Retrieved 22 Oktober 2015, from USC Libraries http://libguides.usc.edu/c.php?g=235034\&p=1559822 
Kobana Salam, Nurdin Nurdin, Pemberdayaan Perpustakaan.....

isu-isu pemanfaatan perpustakaan dalam berbagai literatur yang kami kaji di sesuaikan dengan pemanfaatannya dalam dakwah. Hasil kajian pustaka tersebut akan merupakan sintesis topik-topik inti yang ada dalam bidang yang menjadi kajian tulisan ini. Levi dan Ellis juga berpendapat bahwa meskipun sebuah tulisan ditulis hanya bersumber dari kajian pustaka, penulis tetap harus menjelaskan metodology analisis ${ }^{16}$.

Dalam hal ini, langkah pertama yang kami lakukan adalah melakukan kajian terhadap berbagai literature dibidang ilmu perpustakaan baik yang berupa buku teks maupun jurnal. Selanjutnya kami melakukan kajian terhadap berbagai literature dalam bidang ilmu dakwah dan komunikasi Islam. Hasil kajian literatura dalam kedua bidang ilmu tersebut kami kaji dan analisis untuk mengembangkan bagaimana konsep keberadaan perpustakaan seperti fungsi dan layanannya dapat serasi dengan konsep-konsep ilmu dakwah dan komunikasi Islam. Hasil akhir dari analisa tersebut adalah bahwa cara-cara kerja perpustakaan menyerupai cara-cara kerja ilmu dakwah yaitu mengkomunikasikan informasi kepada masyarakat.

\section{Pembahasan}

Pada bagian ini akan dibahas bagaimana perpustakaan dapat dipamnfaatkan sebagai salah satu sarana dakwah agama Islam. Pembahasan ini dilakukan dengan mempertimbangkan beberapa fungsi perpustkaan yang ditelah disebutkan dalam bagian tinjauan pustaka diatas. Fungsi perpustakaan tersebut dikaitkan dengan kegiatan dakwah yang dapat didukung oleh perustakaan sebagai sumber informasi.

${ }^{16}$ Levy, Y., \& Ellis, T. JA Systems Approach to Conduct an Effective Literature Review in Support of Information Systems Research. Informing Science, 9, 2006), h. 181212 


\section{$\Delta L-\cap i s h \exists \bar{d} h$, Vol. 11 No. 1, Januari-Juni 2015: 47-64}

\section{a. Perpustakaan sebagai sumber informasi dalam mendukung dakwah}

Keberadaan perpustakaan dan pengembangan ilmu pengetahuan merupakan bagian yang tak terpisahkan satu sama lain. Dalam hal ini perpustakaan menyediakan berbagai macam informasi baik dalam bentuk cetak maupun terekan (elektronik) yang berguna bagi pengembangan ilmu pengetahuan, sedangkan untuk memperoleh berbagai informasi bagi pengembangan pengetahuan membutuhkan perpustakaan sebagai sumber informasi.

Perpustakaan sebenarnya suatu lembaga yang membawa misi sosial yang tidak mencari untung. Perpustakaan menyediakan berbagai informasi dan melayankan kepada masyarakat secara cuma-cuma tanpa harus membayar. Sebagai pusat informasi maka perpustakaan memiliki bebera fungsi antara lain:

Fungsi sebagai sumber informasi maksudnya bahwa perpustakaan merupakan lembaga yang menyediakan berbagai macam informasi dalam berbagai bentuk baik tercetak maupun terekam. Bagi masyarakat yang memerlukan informasi dapat memintanya ataupun menanyakan ke perpustakaan. Informasi yang diminta dapat berupa informasi mengenai tugas sehari-hari, pelajaran, maupun informasi lainnya. Dengan koleksi yang ada perpustakaan menjawab setiap yang diajukan ke perpustakaan .

Perhatian Islam terhadap Ilmu Pengetahuan sudah sama-sama kita ketahui dengan diturunkannya Alqurān surah " al-'Alaq" pada permulaan nubuwwah Nabi Muhammad Saw dan ayat-ayat lain yang senada dengan al-'Alaq yang tersebar di dalam Alqurān. Dengan Alqurān ( pena ) yang disebutkan dalam al-'Alaq tersebut maka manusia merumuskan buah fikirannya dan menyatakan pendapatnya. Dengan pena seorang Kepala Negara dapat menyatakan perang dan dapat menyatakan perdamaian. Buah pikiran yang dirumuskan dalam bentuk tulisan inilah yang terdapat di dalam buku-buku yang terdapat di dalam perpustakaan. Dikala Nabi 
Kobana Salam, Nurdin Nurdin, Pemberdayaan Perpustakaan.....

Muhammad Saw harus memusatkan perhatiannya untuk melawan serangan-serangan Kafir Quraisy, sedetikpun beliau tidak pernah alpa terhadap kemajuan ilmu pengetahuan. Tawanan-tawanan perang Badar dibebaskan, apabila mereka dapat mengajarkan tulis baca bagi 10 orang anak muslim.

\section{b. Perpustakaan sebagai tempat studi/ belajar dalam mendukung Dakwah}

Secara umum perpustakaan merupakan sumber informasi, pendidikan, penelitian, preservasi dan pelestari khasanah budaya bangsa serta tempat rekreasi yang sehat, murah dan bermanfaat. Dalam hal ini perpustakaan dapat menjadi media atau jembatan yang berfungsi menghubungkan antara sumber informasi dan ilmu pengetahuan yang terkandung di dalam koleksi perpustakaan dengan para pemakainya. Para dai dan santri merupakan salah satu kelompok pengguna perpustakaan yang membutuhkan informasi dan pengetahuan yang ada di perpustakaan.

Untuk mendapatkan informasi dan pengetahuan tersebut, maka para dai dan santri tersebut perlu melakukan berbagai kegiatan yang terkait dengan belajar baik dalam bentuk membaca berbagai literature yang ada maupun dengan cara melakukan riset kecil-kecilan untuk mengkaji berbagai pengetahuan terkain ke Islaman yang dapat dimanfaatkan untuk berdakwah.

Fungsi perpustakaan sebagai tempat studi/belajar ini sudah dijelaskan oleh Sulistityo Basuki, maksudnya bahwa perpustakaan merupakan sarana pendidikan formal dan non formal artinya perpustakaan dapat dimanfaatkan bukan hanya sebagai sarana belajar baik dilingkungan pendidikan resmi seperti sekolah dan perguruan tinggi, tapi juga dapat dimanfaatkan sebagai sarana belajar diluar pendidikan 


\section{$\Delta L-$-nish $3 \bar{\Delta} /$ H, Vol. 11 No. 1, Januari-Juni 2015: 47-64}

resmi tersebut ${ }^{17}$. Kalau dilingkungan sekolah dan perguruan tingi ada perpustakaan sekolah atau perpustakaan perguruan tinggi, maka di luar lingkungan tersebut ada perpustakaan umum seperti perpustakaan daerah, perpustakaan pribadi, dan perpustakaan mesjid.

Perpustakaan mesjid ini dapat memainkan perannya dalam memelihara ilmu pengetahuan dengan cara menyimpan berbagai literature agar dapat dibaca oleh umat Islam. Hal semacam ini sudah dianjurkan oleh Nabi Muhammad Saw untuk memelihara Ilmu Pengetahuan dan Kesusastraan. Sejak dulu sarjana-sarjana Islam sudah mendirikan Perpustakaan Islam, Perpustakaan Masjid, Perpustakaan Madrasah, Perpustakan Perguruan Tinggi, dan Perpustakaan Pesantren.

Membaca akan membawa seseorang kepada tujuan-tujuan yang diinginkannya dan bahwa buku-buku itu mempunyai daya kekuatan yang dapat merubah keadaan masyarakat. Tentu saja hal ini akan terjadi jika para dai atau umat Islam lainnya menyebarkan pengetahuan dan ilmu tersebut kepada masyarakat luas. Oleh karena itu, minat baca harus mendapat perhatian khusus oleh Islam. Kita sering menjumpai bahwa masyarakat banyak membaca karena tuntutan tertentu saja, misalnya tuntutan ujian-ujian atau hanya sekedar memenuhi kewajiban yang dibebankan oleh para guru dan kyai. Fenomena semacam ini tidak akan membuat perpustakaan menjadi bermanfaat secara maksimal.

Cara yang paling baik untuk meningkatkan minat baca bukan hanya sekedar untuk ujian adalah dengan cara penyediaan berbagai bahan pustaka atau literatur yang dapat membuat para pengguna tertarik untuk membaca. Dalam hal ini perpustakaan perlu mempersiapkan berbagai koleksi yang menarik, terbaru dan sesuai kebutuhan pengguna. Dengan melakukan hal ini, maka akan semakin banyak pengguna yang

${ }^{17}$ Basuki, S. Teknik dan Jasa Dokumentasi. (Jakarta Gramedia Pustaka Utama, 199), h 50 
Kobana Salam, Nurdin Nurdin, Pemberdayaan Perpustakaan.....

datang ke perpustakaan. Dengan demikian rasa ingin tahu dan minat belajar akan semakin meningkat. Akibatnya nanti pengetahuan yang ada diperpustakaan akan dapat disebarluaskan oleh si pengunjung tersebut melalui barbagai bentuk aktifitas dakwah, baik yang dilakukan oleh seorang dai maupun sebagai umat Islam lainnya.

Di samping itu, perpustakaan (misalnya perpustakaan pesantren) dapat memposisikan dirinya dalam memberikan bimbingan kepada ummat untuk giat membaca. Misalnya perpustakaan dapat mengadakan ceramah dalam suatu topik tertentu atau diskusi yang referensi pembicaraannya kembali pada bahan-bahan yang ada di perpustakaan. Dengan demikian perpustakaan telah berperan sebagai lembaga pendidikan nonformal bagi anggota masyarakat/santri dan pengunjung perpustakaan. Mereka dapat belajar secara mandiri (otodidak), melakukan penelitian, menggali, memanfaatkan dan mengembangkan sumber informasi dan ilmu pengetahuan.

\section{c. Sebagai tempat menyimpan dokumentasi untuk kepentingan dakwah}

Pemanfaatan perpustakaan sebagai tempat menyimpan dokumentasi maksudnya bahwa perpustakaan merupakan tempat menyimpan berbagai macam hasil karya manusia. Hasil karya tersebut tidak hanya berupa karya-karya terbaru akan tetapi juga karya-karya bersejarah. Dengan adanya dokumentasi berbagai hasil karya umat manusia maka akan memungkingkan generasi berikutnya menikmati hasil karya manusia terdahulu. Dengan demikian berbagai macam dokumen tetap terpelihara dengan baik tanpa khawatir akan punah.

Dalam Islam banyak sekali karya-karya bersejarah yang tersebar dimana-mana. Karya - karya bersejarah tersebut mengandung banyak pengetahuan, abik pengetahun umum, sejarah dan peradaban umat Islam, dan juga nilai-nilai dan hukum Islam. Buku-buku filsafat Islam, 


\section{$\Delta L-n i s h \exists \bar{\Delta} h$, Vol. 11 No. 1, Januari-Juni 2015: 47-64}

Tasawuf, ilmu-ilmu hadis dan tafsir. Karya-karya tersebut akan lebih tepat dan aman jika disimpan diperpustakaan karena dikelola dengan baik.

Umat Islam dan tokoh Islam seperti para Dai dapat memanfaatkan kembali karya-karya bersejarah tersebut sebagai sumber pengetahuan yang kemudian di dakwahkan kepada umat Islam lainnya. Misalnya literatur-litaratur tentang sejarah Nabi Muhammad Saw dapat disimpan di perpustakaan. Koleksi tersebut kemudian dapat dimanfaatakan oleh para Dai dan umat Islam lainnya untuk disampaikan kepada umat Islam lainnya melalui kegiatan dakwah ${ }^{18}$.

Perpustakaan bukan hanya mendokumentasikan koleksi yang bersifat buku-buku sejarah Islam saja, tapi juga artefak-artefak Islam dari berbagai periode dan lokasi. Artefak-artefak tersebut dapat menjadi saksi perkembangan Islam yang dapat dilihat oleh generasi Islam selanjutnya. Prosen pelestarian tersebut juga dapat dikatakan suatu kegiatan dakwah yang dilakukan oleh perpustakaan kepada ummat Islam di suatu tempat perpustakaan tersebut berada. Dengan demikian pemenfaatan perpustakaan sebagai tempat pendokumentasian sangat erat kaitannya dengan kegiatan dakwah karena mendokumentasi berarti memberi kesempatan untuk sampainya informasi kepada khalayak. Disamping itu perpustakaan telah berperan dalam menghimpun dan melestarikan koleksi bahan pustaka ke Islaman dan artefak lainnya yang merupakan hasil karya umat manusia yang tak ternilai harganya agar tetap terjaga dalam keadaan baik.

Sekain itu, dengan memanfaatkan perpustakaan sebagai pusat dokumentasi Islam, maka upaya pelestarian naskah-naskah peninggalan zaman Islam dahulu yang banyak dijumpai dalam kondisi tidak utuh, dapat dilakukan perbaikan melalui kegiatan restorasi dan kurasi. Sebagai

${ }^{18}$ Haezan, M. Dakwah Rasulullah Saw Menurut Historis Islam (Periode MekahMadinah). Bachelor Skripsi, Sekolah Tinggi Agama Islam Negeri, Surakarta, 2008), h. 22 
Kobana Salam, Nurdin Nurdin, Pemberdayaan Perpustakaan.....

warisan budaya yang memiliki wujud konkret, naskah-naskah kuno Islam sering dikategorikan sebagai warisan budaya benda Islam yang penting dan menuntut penanganan khusus dari pihak perpustakaan.

Upaya pelestarian warisan budaya masa lampau Islam tersebut dapat menjadikan perpustakaan sebagai tempat untuk menyimpan dan menyebarkan ilmu pengetahuan kuno memainkan peranan yang signifikan. Penyimpanan khasanah budaya Islam atau budaya masyarakat tempat perpustakaan berada dapat meningkatkan nilai serta apresiasi budaya dari masyarakat Islam dan sekitar perpustakaan tersebut melalui penyediaan bahan-bahan bacaan bersejarah tersebut. Dengan demikian perpustakaan juga telah berfungsi sebagai pusat kultural umat Islam yang mengarah pada upaya pelestarian nilai-nilai kebudayaan dan sejarah Islam. Perpustakaan juga telah berfungsi sebagai pusat peradaban ${ }^{19}$ karena telah mendokumentasikan dan memeliharan peradaban umat Islam.

\section{d. Sebagaai Tempat Tumbuhnya Ilham dan Inspirasi Dakwah}

Fungsi perpustakaan sebagai tempat tumbuhnya ilham, inspirasi dan rekreasi dapat dipahami bahwa diperpustakaan menemukan ilham dan inpirasi karena terdapat berbagai macam informasi untuk dikaji dan dipelajari. Pemanfaatan perpustakaan sebagai sumber inspirasi telah diteliti oleh Benawi yang menemukan bahwa perpustakaan itu dapat dijadikan sebagai tempat menumbuhkan inspirasi dan ilham jika perpustakaan tersebut di didesain dengan menarik dan indah, disediakan koleksi yang menarik sesuai dengan kebutuhan pengguna atau pemustaka $^{20}$.

${ }^{19}$ Benawi, I. Menjadikan Perpustakaan Sebagai Sumber Informasi Dalam Membagun Peradaban Iqra, 72), 2013, h. 32-40.

${ }^{20}$ Ibid., h. 35-36 


\section{$\Delta L-n i s h \exists \bar{\Delta} h$, Vol. 11 No. 1, Januari-Juni 2015: 47-64}

Disaat masyarakat mengalami kesibukan dan lelah dengan berbagai kegiatan sehari-hari maka perpustakaan dapat menjadi sarana hiburan/rekreatif karena di perpustakaan terdapat berbagai macam buku dan koleksi lainnya yang dapat menghibur disamping buku-buku ilmiah. Fungsi rekreatif ini tampak nyata pada pada perpustakaan umum dimana terdapat ruang baca anak-anak yang banyak menyediakan berbagai macam bacaan anak-anak. Di perpustakaan daerah propinsi misalnya kita dapat melihat banyaknya anak-anak yang mengunjungi ruang baca anakanak terutama disore hari dan hari libur.

Perpustakaan dapat pula berperan sebagai lembaga untuk mengembangkan minat baca, kegemaran membaca, kebiasaan membaca, dan budaya baca, melalui penyediaan berbagai bahan bacaan yang sesuai dengan keinginan dan kebutuhan para umat Islam. Dengan demikian perpustakaan dapat berperan aktif sebagai fasilitator, mediator, dan motivator bagi mereka yang ingin mencari, memanfaatkan, dan mengembangkan ilmu pengetahuan dan pengalamannya.

Pemanfaatan perpustakaan sebagai pusat kegiatan mencari ilham dan inspirasi dapat meningkatkan peran perpustakaan sebagai tempat untuk mendidik dan mengembangkan apresiasi budaya masyarakat. Pendidikan ini dapat dilakukan dengan cara menyelenggarakan pameranpameran ke-Islaman, ceramah, pertunjukan kesenian Islam, pemutaran film-film Islam, bahkan menyediakan cerita-cerita Islami untuk anak-anak. Sehingga berbagai inspirasi ke-Islaman dapat tumbuh dengan baik di perpustakaan.

Akibatnya perpustakaan dapat menjadi agen perubahan, agen pembangunan, dan agen kebudayaan umat manusia. Sebab berbagai penemuan, sejarah, pemikiran, dan ilmu pengetahuan yang tersimpan di perpustakaan baik dapat menumbuhkan inspirasi bagi pembacanya. Ummat Islam dapat memanfaatkan koleksi tersebut untuk dipelajari, diteliti, dikaji, dan dikembangkan yang kemudian dapat dipergunakan 
Kobana Salam, Nurdin Nurdin, Pemberdayaan Perpustakaan.....

sebagai sumber inspirasi dan landasan penuntun untuk merencanakan masa depan umat Islam yang lebih baik.

Dengan diperoleh berbagai inspirasi dan ilham yang positif di perpustakaan maka secara tidak langsung, perpustakaan yang telah berfungsi dan telah dimanfaatkan dengan sebaik-baiknya untuk pengembangan umat yang lebih baik. Perpustakaan telah berperan dalam mengurangi dan mencegah hal-hal negatif dalam kehidupan umat Islam sehari-hari seperti kenakalan remaja, tawuran, penyalah gunaan obatobat terlarang, tindak indisipliner, dan lain-lain.

\section{Penutup}

Perpustakaan sebagai sumber informasi bagi masyarakat dapat dimanfaatkan sebagai sarana instrument pendukung dakwah di kalangan umat muslim. Pemanfaatan perpustakaan sebagai salah satu sarana dakwah dapat dilakukan melalui kegiatan antara lain; pemberdayaan perpustakaan sebagai pusat informasi dakwah, sebagai tempat belajar ilmu-ilmu agama, sebagai tempat dokumentasi karya-karya sejarah dan artefak Islam, dan sebagai tempat untuk menumbuhkan insipirasi dan ilham bagi umat muslim.

Dengan diberdayakan perpustakaan untuk keperluan yang disebut diatas, maka perpustakaan sudah dapat berfungsi sebagai salah satu sumber, media, dan instrumen dakwah Islam. Peran Dai bisa lebih terbantu karena umat Islam dapat memperoleh berbagai pengetahuan keIslaman di perpustakaan. Umat Islam dapat lebih meningkatkan dan memberdayakan dirinya secara mandiri diperpustakaan dengan melakukan hal-hal yang positif.

\section{Daftar Pustaka}

Basuki, S. Teknik dan Jasa Dokumentasi. Jakarta Gramedia Pustaka Utama, 1991. 


\section{$\Delta L-\cap i s h \exists \bar{d} h$, Vol. 11 No. 1, Januari-Juni 2015: 47-64}

Benawi, I. Menjadikan Perpustakaan Sebagai Sumber Informasi Dalam Membagun Peradaban Iqra, 72), 2013.

Freeman, G. T. The Library as Place: Changes in Learning Patterns, Collections, Technology, and Use. In K. Smith (Ed.), Library as Place: Rethinking Roles, Rethinking Space. Washington DC: Council on Library and Information Resources, 2005.

Haezan, M. Dakwah Rasulullah Saw Menurut Historis Islam (Periode Mekah-Madinah). Bachelor Skripsi, Sekolah Tinggi Agama Islam Negeri, Surakarta, 2008.

Hamid, I. al-Da'wah Ila Allah bi al-Hikmah wa al-Maw'izah al-Hasanah. Mesir: al-Hay'ah al-Mis\}riyyah al-'Ammah, 1996.

IFLA. Information for All : The Key Role of Libraries in the Information Society (pp. 17). Geneva: INTERNATIONAL FEDERATION OF LIBRARY ASSOCIATIONS AND INSTITUTIONS (IFLA), 2003.

Indonesia, Undang-Undang Republik Indonesia Nomor 43 Tahun 2007 Tentang Perpustakaan, 2007.

Irsan. (Ziarah Perpustakaan Di Makassar). 2014. Retrieved 25 Oktober 2015 , from

Wordpress

https://airsunblog.wordpress.com/2014/09/26/ziarahperpustakaan-di-makassar/

Labaree, R. (2013). Organizing Your Social Sciences Research Paper: The Literature Review. Retrieved 22 Oktober 2015, from USC Libraries http://libguides.usc.edu/c.php?g=235034\&p=1559822

Lasa, H. (1993). Kamus Istilah Perpustakaan. Yogyakarta Kanisius.

Levy, Y., \& Ellis, T. J. A Systems Approach to Conduct an Effective Literature Review in Support of Information Systems Research. Informing Science, 9, 2006. 
Kobana Salam, Nurdin Nurdin, Pemberdayaan Perpustakaan.....

Mulyana, D. Nuansa-Nuansa Komunikasi Masyarakat Kontemporer (1 ed.). Bandung: Remaja Rosdakarya, 1999.

Natsir, M. Fiqhud Dakwah. Jakarta: Dewan Dakwah Islamiah Indonesi, 1977.

Suhaimi. Dakwah and Communication Programmes in Tertiary Higher Education in Indonesia: A Brief Survey. Islamiyyat, 34, 2012.

Suyuti, A. Amtsilatu Tasrifiyah. Yogyakarta: Mitra Pustaka. 1997.

Webster, J., \& Watson, R. T. Analyzing the Past to Prepare for the Future: Writing a Literature Review. MIS Quarterly, 26(2), 2002. 